\title{
First bat records in the Simien Mountains (Northern Ethiopia)
}

\author{
Sergei V. Kruskop \& Leonid A. Lavrenchenko
}

\begin{abstract}
No any bat records were known previously from the Simien Mountains National Park (Northern Ethiopia) while two bat species were reported from the Simien foothills. During the work of Ethiopian-Russian Biological Expedition two bat species were captured at the elevation of ca. $3250 \mathrm{~m}$. Males of Pipistrellus from the "kuhlii" species group were captured or observed several times in anthropogenous landscapes. According to multivariate analysis these pipistrelles are similar to $P$. cf. kuhlii from southern part of the country and to P. hesperidus. One captured female of Laephotis wintoni represents most northern and highest elevation record of the genus.
\end{abstract}

KEY WORDS: Pipistrellus kuhlii, Laephotis wintoni, Simien Mountains, Ethiopia, new records.

SergeiV. Kruskop [kruskop@zmmu.msu.ru], Zoological Museum, Moscow State University, ul. Bolshaya Nikitskaya 6, Moscow 125009, Russia; Leonid A. Lavrenchenko, A.N.Severtsov Institute of Ecology and Evolution, Russian Academy of Sciences, Leninsky pr. 33, Moscow 119071, Russia.

\section{Первые находки летучих мышей в Симиенских горах (Северная Эфиопия)}

\section{С.В. Крускоп, Л.А. Лавренченко}

РЕЗЮМЕ. Летучие мыши ранее не были известны с территории национального парка Симиенские Горы (Северная Эфиопия); лишь два вида рукокрылых указываются для подножия этого горного массива. Во время работы Российско-Эфиопской Биологической Экспедиции два вида летучих мышей были обнаружены на высоте около 3250 м над ур. м. Самцов нетопырей из группы видов “Pipistrellus kuhlii" неоднократно наблюдали и отлавливали в различных антропогенно нарушенных ландшафтах. Результаты многофакторного анализа показали, что эти нетопыри наиболее сходны с P. cf. kuhlii с юга страны и с P. hesperidus. Единственная пойманная самка Laephotis wintoni представляет собой наиболее северную и высокогорную находку для этого рода.

КЛЮЧЕВЫЕ СЛОВА: Pipistrellus kuhlii, Laephotis wintoni, Симиенские горы, Эфиопия, новые находки.

\section{Introduction}

Situated in the western sector of the magnificent Simien Massif in northern Ethiopia, the Simien Mountains National Park (SMNP) covers an area of $179 \mathrm{~km}^{2}$ and ranges from $1900 \mathrm{~m}$ to $4430 \mathrm{~m}$ ASL. The highlands are dominated by afroalpine grasslands, short-grass pastures, tree-heather - Hypericum woodlands and montane broad-leaved forests. This relatively small Park receives international attention due to its biodiversity, high number of endemic species and outstanding physical features. Particularly, it is of critical importance for a number of rare and endangered larger mammals, Walia ibex Capra walie, Simian jackal Canis simensis and gelada baboon Theropithecus gelada. The declaration of the SMNP as a World Heritage Site in 1978 stimulated the development of a number of research and conservation projects for this area. Detailed survey of the flora and fauna of the SMNP was performed by Swiss scientists (Nievergelt et al., 1998). Nevertheless, no documented reports about bats (Chiroptera) where made from the Park. The closest record was known from the lower flow of the Belegez River, on the southern slope of the Simien Massif. In this locality two bat species were collected: Ethiopian woolly bat Kerivoula cf. lanosa (the type specimen of Kerivoula eriophora) and Ethiopian epauletted fruit bat Epomophorus labiatus (Largen et al., 1974). The latter one was also reported to the Simien, however this must be mistake because of the absence in the Simien highlands of any habitats suitable for fruit bats. Nevertheless, there were no doubts that some bat species may occur even in the highland part of the Simien Mountains, including territory of the SMNP.

During April and May, 2005 the Mammal Research Group of the Joint Ethio-Russian Biological Expedition (JERBE II) have provide field work in the SMNP aiming to the investigation of small mammals fauna. In the ranks of this work several bat individuals were captured representing first documented records of Chiroptera from the SMNP territory. All these specimens are deposited in the collection of the Zoological Museum of the Moscow State University (ZMMU). 


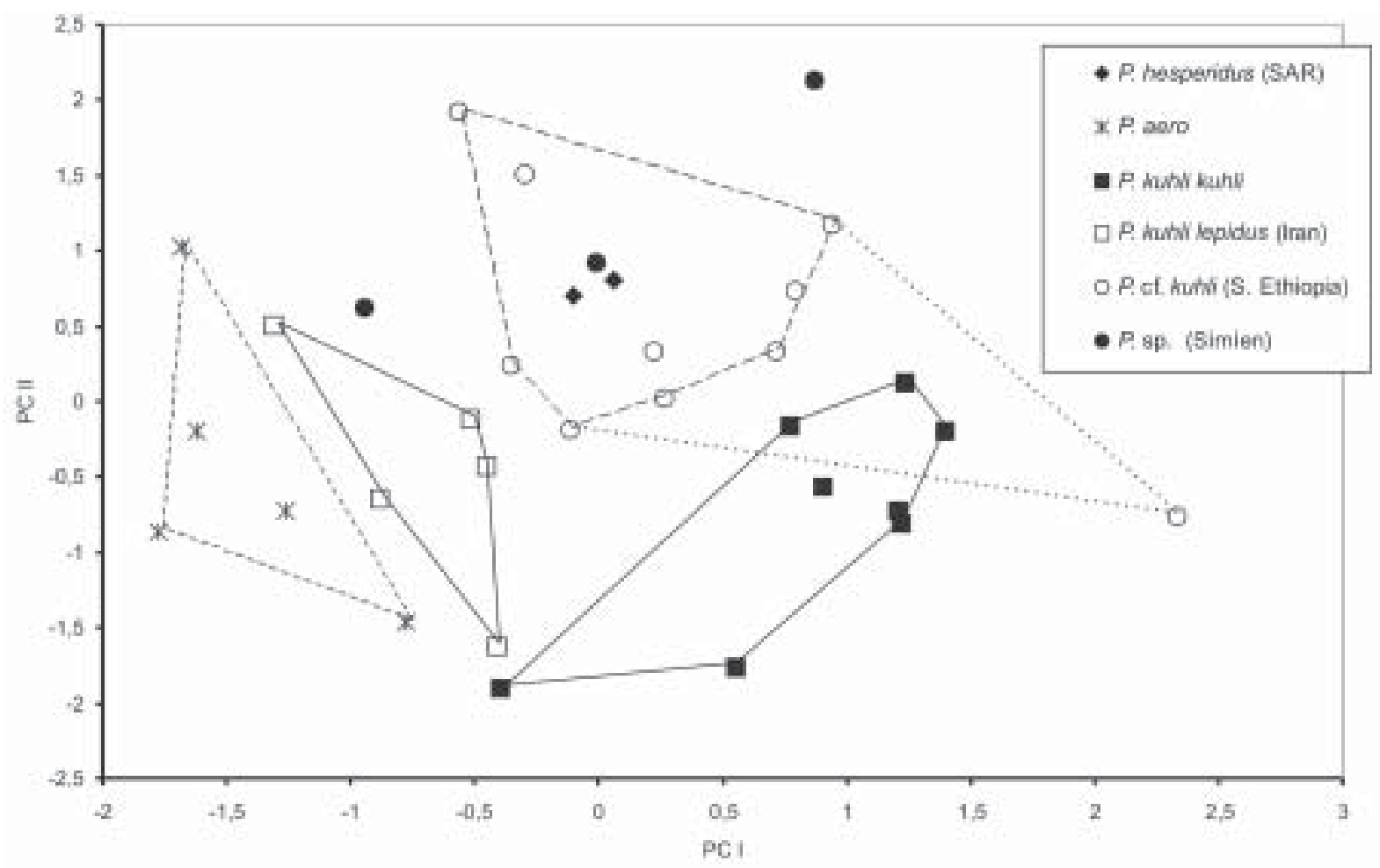

Figure 1. Bivariate scatterplot of relative position of Pipistrellus specimens in the plane of the two first principal components (PC I and PC II), calculated on the basis of 16 craniodental measurements.

\section{Materials and methods}

For bat capturing "traditional" mist nets $(7 \times 2 \mathrm{~m})$, positioned across the possible bat's flight paths, were used together with mobile trap, representing nylon $2 \times 2$ $\mathrm{m}$ net put on the two carboplastic fishing rods (Borissenko, 1999). For field observations the narrow-band heterodine ultrasound detector (D-100, Petterson Electronic $\mathrm{AB}$ ) was used.

The captured bats were preserved in $70 \%$ ethanol, and then in the laboratory conditions their skulls were extracted for measuring. The following 16 cranial measurements were took to the nearest $0.01 \mathrm{~mm}$ with an electronic calipers in combination with a binocular microscope: condylocanine length, condylobasal length, mastoid width, width of braincase, occipital height of the skull, width of postorbital constriction, rostral width at the level of the infraorbital foramina, rostral length from infraorbital foramen to the anterior margin of the upper jaw, C-M3 length, length of the upper canine cingulum base, width across outer margins of upper canines, width across outer margins of M3, length of the palate from the anterior margins of canines to the most posterior point of palate midline, crown length of maxillary tooth row, lower jaw length from alveolus of i1 to the articulated process, lower jaw height to the tip of coronoid process. For the comparison of some specimens with related forms the principal component analysis and discriminant analysis were conducted using Statistica for Windows, v.5.1. All the measurements were standardize to the general dispersion to reduce size influence.

We compare our Simien individuals with five specimens of $P$. aero, ten specimens of $P$. cf. kuhlii (all from more southern parts of Ethiopia), 13 P. kuhlii (eight from Caucasus and five from Iran), and two $P$. hesperi$d u s$ from South Africa. South African P. hesperidus specimens are deposed in the collection of the Geneva Museum of Natural History (GMNH), all other mentioned specimens are in the collection of Zoological Museum of Moscow University (ZMMU). Only adult animals of both sexes were taken for comparison. Part of the Ethiopian individuals was decently identified by Victor V. Cakenberghe at the Antwerp University.

\section{Results}

During our fieldwork, two bat species were collected in the vicinity of the Sankaber campsite $(3250 \mathrm{~m}$ ASL, $\left.13^{\circ} 14^{\prime} \mathrm{N}, 38^{\circ} 03^{\prime} \mathrm{E}\right)$. No any bat was observed or collected nearby the Chennek campsite (3650 m ASL, $\left.13^{\circ} 15^{\prime} \mathrm{N}, 38^{\circ} 13^{\prime} \mathrm{E}\right)$ probably because of too high elevation.

Pipistrellus cf. kuhlii - pipistrelle bat. The small pipistrelle bats were simultaneously observed in the late evening time in the Sankaber campsite as well as in the natural habitats. They demonstrate typical pipistrelle pattern of the foraging behavior, flaying over the bushes and along forest edges about two to seven meters from the ground and emitting moderately shallow FM 
signals at $35-45 \mathrm{kHz}$, with maximum energy around 40 $\mathrm{kHz}$. Several individuals of this bat type inhabited one of the buildings in the campsite, not using by scouts or tourists. Three individuals (all adult but reproductively inactive males) were captured: one near the main road, over a small pasture, surrounded with bushes, one emerging from the building and the third - over the bushes in natural habitat. All three individuals (ZMMU S-178763, S-178471, and S-178472) are tentatively allocated to the same species of "true" pipistrelle, Pipistrellus s. str., because of the general appearance, presence of calcareal lobe, small premolars and by nyctalodont lower molars.

By general size these specimens more or less resemble P. kuhlii, $P$. hesperidus and $P$. aero.

Results of the principal components analysis based on these measurements can be seen on Fig. 1. First component PC I (eigenvalue 9.415; total variance is $58.85 \%$ ) has higher correlations with condylobasal and condylocanine lengths of skull and with mastoid width; second component PC II (eigenvalue 2.474; total variance is $15.46 \%$ ) has higher correlations with rostral width, width across upper canines and width across posterior upper molars. It can be seen on the scatterplot that Ethiopian kuhlii-like pipistrelles have no overlap with both mentioned samples of $P$. kuhlii despite one extremely large individual. The Simien specimens look more similar Ethiopian $P$. cf. kuhlii than any other species, and in any case more similar than $P$. aero. However, South African P. hesperidus also more correspond to $P$. cf. kuhlii.

The similar situation was shown by the discriminant analysis, where four groups were set as initially determined: P. kuhlii kuhlii, $P$. k. lepidus, $P$. cf. kuhlii and $P$. aero. According to posterior probabilities, both Simien specimens and $P$. hesperidus were assigned to $P$. cf. kuhlii. Squared Mahalanobis distances between the Simien individuals and centroids of the mentioned samples are minimal in the case of $P$. cf. kuhlii. However, value of these distances is distinctly higher than that inside one sample and comparable to the distance between two subspecies of $P$. kuhlii (Tab. 1).

Most of the kuhlii-like pipistrelles from the subSaharan Africa were recently assigned to their own species, P. hesperidus, distinct from P. kuhlii (Kock, 2001). However, interrelations between these two species seem to be not clear, as well as allocation of many named forms, described from Africa. According to our analysis, all the Simien individuals should be assigned to the same species as South Ethiopian P. cf. kuhlii, well divided from $P$. aero. This species looks similar to both $P$. kuhlii and $P$. hesperidus, which unfortunately was represented in the analysis by insufficient sample. Final solution of this problem may be obtained by the analysis of DNA sequences. Level of difference between Simien and South Ethiopian specimens gives ground for suggestion that there is some intraspecific variability of $P$. cf. kuhlii on the territory of Ethiopia.

Laephotis wintoni-big-eared serotine. The single adult female was captured by the mist net close to the Sankaber campsite. This record is very distant from the previous findings in Awash and the Beletta Forest (Lavrenchenko et al., 2004) and represents the northmost record of the genus. Also all the previous records were made on the distinctly lower elevations, not greatly exceed 2000 m ASL (Peterson, 1971, 1973; Lavrenchenko et al., 2004). Very few are known about biology of this species. Probably it can be associated with various habitats. Previous Ethiopian record was made in relatively thick woodland. Kingdon (1974) reported that most known records were made under the tree bark. Our specimen was captured on the open place, partially covered with bushes and tree-like heathers. It looks very probable that dry woodlands on the slopes of gorges represent the main habitat for this species in the Simien Mountains. Both external and cranial dimensions of our specimen ZMMU S-178705 (forearm length $38.7 \mathrm{~mm}$; ear length $20.8 \mathrm{~mm}$; condylobasal length $15.93 \mathrm{~mm}$; mastoid width $8.43 \mathrm{~mm}$; width across outer margins of upper canines $4.69 \mathrm{~mm}$; C-M3 length 5.40

Table 1. Squared Mahalanobis distances to the centroids of the four Pipistrellus kuhlii-like samples. Distances to the centroids inside each sample are marked with bold.

\begin{tabular}{|l|c|c|c|c|}
\hline \multirow{2}{*}{ Species name; n or coll. No. } & \multicolumn{4}{|c|}{ Groups } \\
\cline { 2 - 5 } & aero & kuhlii kuhlii & kuhlii lepidus & cf. kuhlii \\
\hline P. aero (Ethiopia), $\mathrm{n}=5$ & $\mathbf{8 . 2 2}-\mathbf{1 3 . 4 9}$ & $91.31-131.64$ & $65.18-117.26$ & $104.96-166.99$ \\
\hline P. kuhlii kuhlii (Caucasus), $\mathrm{n}=8$ & $85.47-139.64$ & $\mathbf{8 . 2 8 - 1 7 . 9 4}$ & $50.91-103.61$ & $40.14-99.18$ \\
\hline P. kuhlii lepidus (Iran), $\mathrm{n}=5$ & $66.27-97.41$ & $63.47-93.65$ & $\mathbf{5 . 5 8 - 1 1 . 7 7}$ & $178.15-206.28$ \\
\hline P. cf. kuhlii (S Ethiopia), $\mathrm{n}=10$ & $91.88-162.33$ & $56.95-93.29$ & $154.03-227.64$ & $\mathbf{8 . 9 3 - 1 7 . 3 5}$ \\
\hline P. hesperidus (S Africa), GMNH M986 & 241.10 & 167.35 & 390.23 & 56.39 \\
\hline P. hesperidus (S Africa), GMNH M994 & 131.00 & 50.49 & 173.08 & 7.05 \\
\hline P. sp. (Simien), ZMMU S-178471 & 296.59 & 127.56 & 287.89 & 70.88 \\
\hline P. sp. (Simien), ZMMU S-178472 & 180.98 & 75.27 & 193.86 & 39.40 \\
\hline P. sp. (Simien), ZMMU S-178763 & 221.89 & 132.72 & 182.77 & 93.19 \\
\hline
\end{tabular}


$\mathrm{mm})$ are well correspond with that of other individuals from East Africa (Peterson, 1971, 1973).

Actually, the number of bat species in the SMNP must be higher, because at least two else types of bats were recorded visually and by ultrasound bat detector (also in the vicinity of the Sankaber campsite). One of them in general shape and FM echolocation signals with maximum energy around $30-35 \mathrm{kHz}$ is similar to the bent-winged bat (Miniopterus). In the Bale Mountains one species of this genus, $M$. africanus inhabits elevations similar to that in the Sankaber area (Lavrenchenko et al., 2004), so this supposition seems to be realistic. The second type of bats was recorded mainly by loud audible calls poorly recorded by bat detector. According to the calls, these bats fly with relatively high speed and usually (but not always) far from the ground and initially were identified as representatives of Molossidae. Unfortunately, these two types of bats were not captured and so there was no possibility for their exact identification.

ACKNOWLEDGMENTS. We are indebted to the Agricultural Bureau of Amhara Regional State (Bahr-Dar) for permission to work in the Simien Mountains National Park and to the Natural Resources Sector of the Ministry of Agriculture for permission to export of specimens. We also thank the warden and staff of the Simien Mountains National Park for the use of the Park buildings and equipment.We are indebted to our Project Coordinators Dr. Andrei Darkov (Joint Ethio-Russian Biological Expedition, Second Phase JERBE II) and Ato Girma Yosef (Ethiopian Science and Technology Commission) for management of the expedition in the field and in Addis Ababa.

We are indebted also to Ato Tariku Tesema (Ethiopian Science and Technology Commission) for permanent sup- port of our work Also we would like to address our special gratitude to Zelalem Endale for his invaluable assistance during all stages of the expedition. We especially thank Dr. Victor Van Cakenberghe for examining critical specimens of Pipistrellus cf. kuhlii. Specimens of Pipistrellus hesperidus were investigated in Geneva Natural History Museum. Visit of the first author to this museum was organized by Dr. Manuel Ruedi. All other comparative material was represented by Zoological Museum of Moscow State University.

\section{References}

Kingdon J. 1974. East African Mammals. An Atlas of Evolution in Africa. Vol. II, part A (Insectivores and Bats). London and New York: Academic Press. 340 p.

Kock D. 2001. Identity of the African Vespertilio hesperida Temminck 1840 (Mammalia, Chiroptera, Vespertilionidae) // Senckenbergiana Biologica. Vol.81. P.277-283.

Largen M.J., Kock D. \& Yalden D.W. 1974. Catalogue of the mammals of Ethiopia. I. Chiroptera // Monitore Zoologico Italiano. N.S. Supplemento. Vol.16. P.221-298.

Lavrenchenko L.A., Kruskop S.V. \& Morozov P.N. 2004. Notes on the bats (Chiroptera) collected by the Joint Ethiopian-Russian Biological Expedition, with remarks on their systematics, distribution and ecology // Bonner Zoologische Beitrage. Vol.52. No.1/2. P.127-147.

Nievergelt B., Good T. \& Guttinger R. (eds.) 1998. A survey on the flora and fauna of the Simen Mountains National Park, Ethiopia // Walia, Special issue. P.1-109.

Peterson R.L. 1971. Notes on the African long-eared bats of the genus Laephotis (family Vespertilionidae) // Canadian Journal of Zoology. Vol.49. No.6. P.885-888.

Peterson R.L. 1973. The first known female of the African long-eared bat Laephotis wintoni (Vespertilionidae: Chiroptera) // Canadian Journal of Zoology. Vol.51. No.6. P.601-603. 